\title{
Vascular Endothelial Growth Factor Levels in Chronic Hepatitis and Liver Cirrhosis Associated with Hepatitis C
}

\author{
Hepatit C'ye Bağı Kronik Hepatit ve Karaciğer Sirozu Hastalarında Vasküler Endotelyal \\ Büyüme Faktör Düzeyleri
}

\author{
Kenan Çadırcı', Havva Keskin'², Nihat Okçu ${ }^{3}$ \\ ${ }^{1}$ Department of Internal Medicine, University of Health Sciences, Erzurum Regional Training and Research Hospital, Erzurum; ${ }^{2} D e p a r t m e n t$ \\ of Internal Medicine, İstanbul Medeniyet University Göztepe Training and Research Hospital, Istanbul; ${ }^{3}$ Department of Gastroenterology, \\ Erzurum Atatürk University Faculty of Medicine, Erzurum, Turkey.
}

\begin{abstract}
Aim: The hepatitis $C$ virus is a significant public health problem across the world. The purpose of this study is to investigate whether serum Vascular Endothelial Growth Factor (VEGF) can be used as a non-invasive marker of liver damage in patients with hepatitis $C$ virus infection-related chronic hepatitis (Chronic Hepatitis $\mathrm{C}-\mathrm{CHC}$ ) and liver cirrhosis (LC).
\end{abstract}

Material and Method: A total of newly diagnosed 44 patients (34 with $\mathrm{CHC}$ and 10 with $\mathrm{LC}$ ) and 28 healthy subjects were recruited into the study. All the patients had not yet received any treatment for the disease. Detailed medical histories and systemic examination were recorded for all study participants. Also, biochemical and hematological parameters, viral markers, VEGF levels, and upper abdominal ultrasounds were evaluated for all study participants. All subjects in the patient group also underwent biopsy of the liver. Serum VEGF levels were determined by ELISA method.

Results: Mean CHC, LC and healthy control group VEGF levels were $255 \pm 237 \mathrm{pg} / \mathrm{ml}, 198 \pm 130 \mathrm{pg} / \mathrm{ml}$, and $78 \pm 27 \mathrm{pg} / \mathrm{ml}$, respectively. VEGF values in CHC group were significantly higher as compared to the controls $(p 1<0.001)$, but the elevation in the LC group was not statistically significant $(p 2=0.06)$. VEGF levels of the $\mathrm{CHC}$ group decreased as degrees of fibrosis, based on Ishak Fibrosis Scores increased. Similarly, VEGF levels of the LC group decreased as Child-Turcotte-Pugh (CTP) scores increased at subgroup analysis based on the CTP classification system. Additionally, a VEGF level above $115 \mathrm{pg} / \mathrm{ml}$ was determined to predict development of chronic hepatitis with $67 \%$ specificity and $79 \%$ sensitivity, but any VEGF level was unable to predict the development of $L C$.

Conclusion: Serum VEGF levels may be used as a non-invasive marker of progressive damage and regeneration occurring in the liver, but the current findings need to be supported with randomized controlled trials involving wider patient groups.

Key words: hepatitis C virus; VEGF; fibrosis; chronic hepatitis; liver cirrhosis
ÖZET

Amaç: Hepatit C virüsü, dünya genelinde önemli bir halk sağlığı sorunudur. Bu çalıșmamızın amacı, hepatit C virüs enfeksiyonu ilișkili kronik hepatit (Kronik Hepatit C- KHC) ve karaciğer sirozu (KCS) olan hastalarda serum Vasküler Endotelyal Büyüme Faktörü (VEGF)' nün, karaciğer hasarının noninvazif bir belirteci olarak kullanılıp kullanılmayacağını araștırmaktı.

Materyal ve Metot: Çalıșmaya yeni tanı konulmuș 44 hasta (34'ü KHC ve 10'u KCS) ve 28 sağlıklı kiși alındı. Hastalardan hiçbiri karaciğer hastalığı için henüz herhangi bir tedavi almamıștı. Tüm çalıșma katılımcıları için ayrıntıı tıbbi öyküler ve sistemik muayene kaydedildi. Ayrıca tüm katılımcıların biyokimyasal ve hematolojik parametreleri, viral belirteçleri, VEGF düzeyleri ve üst abdominal ultrasonografik değerlendirilmeleri yapıldı. Hasta grubunda yer alan tüm hastalara karaciğer biyopsisi uygulandı. Serum VEGF düzeyleri ELISA yöntemi ile çalıșildı.

Bulgular: KHC, KCS ve sağlıklı kontrol grubunun ortalama VEGF değerleri sırasılla: $255 \pm 237 \mathrm{pg} / \mathrm{ml}, 198 \pm 130 \mathrm{pg} / \mathrm{ml}$ ve $78 \pm 27 \mathrm{pg} /$ $\mathrm{ml}$ olarak tespit edildi. Kontrol grubuna göre KHC grubunun VEGF değeri anlamlı derecede yüksek $(p 1<0.001)$ iken, KCS grubunun VEGF değer yüksekliği ise anlamlı değildi (p2=0.06). KHC grubunun Ishak skoru göz önüne alınarak yapılan fibrozis evrelemesine göre, fibrozis derecesi arttıkça VEGF düzeylerinin azaldığı gözlendi. Benzer șekilde KCS grubunda da Child-Turcotte-Pugh (CTP) evreleme sistemine göre yapılan alt grup analizlerinde CTP skoru ilerledikçe VEGF düzeylerinin azaldığı tespit edildi. Ayrıca, VEGF'in $115 \mathrm{pg} / \mathrm{ml}$ üzerinde tespit edilmesi kronik hepatit gelișmesini \%67 spesifite ve \%79 sensitivite ile predikte edebileceği, ancak KCS gelișmesini predikte edebilme özelliğinin olmadığı gösterildi.

Sonuç: Serum VEGF düzeylerinin karaciğerde meydana gelen progressif bir harabiyetin ve rejenerasyonun noninvazif bir göstergesi olarak kullanılabileceği, ancak mevcut verilerin daha geniș hasta gruplarında çalıșmalar ile desteklenmesi gerektiği sonucuna varıldı.

Anahtar kelimeler: hepatitis C virüsü; VEGF; fibrozis; kronik hepatit; karaciğer sirozu

IIletișim/Contact: Kenan Çadirci, Erzurum Regional Training and Research Hospital, Department of Internal Medicine, 25070, Erzurum, Turkey • Tel: 05443444270 • E-mail: doktorcadirci@hotmail.com • Geliș/Received:15.12.2018 • Kabul/Accepted: 28.05.2019

ORCID: Kenan Cadircı, 0000-0002-2765-4288 • Havva Keskin, 0000-0003-1794-4473 • Nihat Okçu, 0000-0002-0457-7945 


\section{Introduction}

According to the World Health Organization (WHO), approximately 71 million people worldwide have chronic hepatitis $\mathrm{C}$ (CHC) infection, and approximately 399.000 people die every year from CHC-related diseases such as cirrhosis and hepatocellular carcinoma ${ }^{1}$. Therefore, hepatitis $\mathrm{C}$ and hepatitis $\mathrm{C}$ related diseases remain a worldwide serious public health problem.

Hepatitis $\mathrm{C}$ virus (HCV) infection causes liver damage in many patients with the development of varying degrees of inflammation and fibrosis. The main complication of chronic HCV infection is liver fibrosis ${ }^{2}$. The fibrotic tissue can be increased by intrahepatic hypoxia. This increased fibrosis causes resistance to intrahepatic blood flow. Local inflammatory reactions also occur in several diseases of the liver ${ }^{3}$. This hypoxia and inflammation are one of the main stimulants of angiogenesis, defined as the formation of new vessels from pre-existing vessels. Physiological angiogenesis occurs during liver regeneration and increases to new functional sinusoids, while pathological angiogenesis emerges in the presence of fibrosis ${ }^{4}$. Angiogenesis is a complex and dynamic process regulated by numerous pro-angiogenic and anti-angiogenic molecules, and in which Vascular Endothelial Growth Factor (VEGF) plays a key role ${ }^{5}$ VEGF is a growth factor specific to endothelial cells that plays a regulatory role in physiological angiogenesis as well as in pathological angiogenesis ${ }^{6,7}$.

Liver fibrosis is characterized by the excessive accumulation of extracellular matrix (ECM) components, the primary source of which are activated hepatic stellate cells (HSC) ${ }^{8}$. Fibrosis developing in tissue is directly associated with HSC activation ${ }^{2}$. When liver tissue is damaged by factors such as various toxins, hepatitis, autoimmune diseases, and steatohepatitis, HSCs are activated by inflammatory mediators and respond to the damage in the liver with an intensive increase in ECM through conversion into a myofibroblast-like phenotype. Several signaling pathways and effectors are involved in liver fibrosis, and VEGF and its receptors is the most important growth factor signal in the initiation of angiogenesis?. VEGF and its receptors can also be expressed by HSCs activated as a response to hypoxic stimuli and during liver injury ${ }^{10}$.

There has always been considerable interest in the role of VEGF in showing liver damage and progression of disease in chronic hepatitis $(\mathrm{CH})$, a progressive disease characterized by inflammation, hepatocellular necrosis and fibrosis, and in cases of $\mathrm{LC}$ occurring with the progression of that disease. The purpose of this study was to determine whether VEGF can be used as a noninvasive marker of disease progression in chronic liver diseases resulting from $\mathrm{HCV}$ infection.

\section{Material and Method}

Forty-four patients (27 male, mean age 55.6 \pm 14.5 years; and 17 women, mean age $54.5 \pm 14.0$ years) who were diagnosed with $\mathrm{CHC}$ and hepatitis $\mathrm{C}$-related LC at Erzurum Ataturk University Faculty of Medicine, Department of Gastroenterology and Department of Internal Medicine Clinic were recruited into the study for more than one year. Patients were divided into two groups depending on diagnosis, a CHC group (34 patients, mean age $51.0 \pm 12.7)$ and a LC group (10 patients, mean age $69.5 \pm 8.2$ ). For the control group, 28 healthy individuals ( 17 men and 11 women, mean age $51.7 \pm 18.1)$ were enrolled into the study. Detailed histories were taken, and detailed physical examinations were done for all participants including cases and controls. In addition, biochemical and hematological parameters were measured after 12 -h fasting, and viral markers and upper abdominal ultrasound were investigated. In addition to these procedures, all subjects in the patient group underwent a liver biopsy. Definite diagnoses were made because of a review of these parameters. All procedures were in accordance with the ethical standards of the institutional and/or national research committee and with the 1964 Helsinki Declaration and its later amendments or comparable ethical standards. All participants gave their written informed consents to participate in the study, and the study was approved by the local ethics institute

\section{VEGFAssay}

Ten milliliters of blood were collected from all patients and healthy controls following 12-h fasting. All blood samples were placed into dry and sterile experimental tubes. After being left to stand for approximately $45 \mathrm{~min}$, the specimens were centrifuged at $4000 \mathrm{rpm}$ for serum separation. Next, $500 \mu \mathrm{l}$ of serum samples were placed into Eppendorf tubes and stored at $-80^{\circ} \mathrm{C}$ until VEGF assay. The remainder of the sera samples were used for routine biochemical procedures. Sera set aside for microbiological study were sent to the microbiology laboratory. Serum VEGF assay was performed in the biochemistry department using ELISA with ready-made commercial kits. The results were expressed as $\mathrm{pg} / \mathrm{ml}$ (RayBio, Human VEGF, Cat\#ELH-VEGF-001, Georgia, USA). 


\section{Viral Marker Assay}

Serological markers from our entire patient and control groups were studied in the hospital Microbiology Laboratory. The Anti-HCV test was performed using ELISA (Anti-HCV: DIA. PRO one Diagnostic Bioprobes SRL, Milan, Italy. $3^{\text {rd }}$ generation). The HCV RNA test was performed using PCR on a RealTime Bio-Rad Thermal Cycler device for nucleic acid isolation, and a Fluorion HCV QNP v2.1 (Iontek A. S., Turkey) for PCR amplification.

\section{Radiological Technique}

All participants in the patient and control groups underwent upper abdominal ultrasonography.

\section{Histological and Clinical Analysis}

All patients in the study were diagnosed using a biopsy. The biopsy materials were evaluated pathologically, and necroinflammation grade and fibrosis stage were determined accordingly. The classification was based on the modified Knodel (Ishak) scoring system ${ }^{11}$. No groups were constituted based on the degree of necroinflammation in this study. Patients were divided into six groups (F1, F2, F3, F4, F5, and F6), based on the stage of biopsy, fibrosis was determined histologically using the Ishak scoring system. Due to the low number of patients, F1 fibrosis was classified as Stage A, F2-F3 as Stage B, F4 as Stage C, and F5-F6 as Stage LC (cirrhosis). Intra-stage LC group evaluation was performed using the ChildTurcotte-Pugh (CTP) system ${ }^{12,13}$.

\section{Statistical Analysis}

Since the groups were not normally distributed, intergroup comparisons were performed using the MannWhitney U test. Pearson's correlation coefficient was used to examine relations among variables. Student's $t$ test was used and the numerical values were expressed as arithmetic mean \pm standard deviation. Receiver Operating Characteristic (ROC) curve analysis was employed to determine a cut-off point for VEGF in predicting the development of chronic hepatitis. The $\mathrm{p}<0.05$ was regarded as statistically significant. Statistical analyses were performed on SPSS for Windows, version 17.0 software (IBM-SPSS, Chicago, USA).

\section{Results}

The healthy group consisted of 28 subjects ( 17 men and 11 women) with a mean age of $51.7 \pm 18.1$ years and a mean VEGF value of $78 \pm 27 \mathrm{pg} / \mathrm{ml}$. The CHC group consisted of 34 patients (20 men and 14 women) with a mean age of $51.0 \pm 12.7$ years and a mean VEGF value $255 \pm 237 \mathrm{pg} / \mathrm{ml}$. VEGF levels were significantly higher in the $\mathrm{CHC}$ group than in the control group $\left(\mathrm{p}_{1}<0.001\right)$ (Table 1). Based on fibrosis stages elicited from pathological study based on the Ishak scoring system, the CHC group consisted of nine Stage A patients, 11 Stage $\mathrm{B}$, and 14 Stage C. Mean VEGF values were $338 \pm 197$ $\mathrm{pg} / \mathrm{ml}$ for Stage A, $238 \pm 289 \mathrm{pg} / \mathrm{ml}$ for Stage B, and $214 \pm 218 \mathrm{pg} / \mathrm{ml}$ for Stage C (Figure 1). Statistical analysis among the three groups revealed a significant difference between Stage A and Stage B $(p=0.04)$, but none between Stage A and Stage C $(p=0.2)$, nor between Stage B and Stage C ( $p=0.7)$. VEGF values decreased as a degree of fibrosis in the CHC group increased. In addition, a significant correlation was observed between the necroinflammation score and the stage of fibrosis in the $\mathrm{CHC}$ group, with necroinflammation score rising in line with fibrosis $(r=0.975, \mathrm{p}=0.000)$.

The LC group consisted of 10 patients ( 7 men and 3 women) with a mean age of $69.5 \pm 8.2$ years. There were five patients in Child A and five patatients in Child B according to the CTP classification system. Mean VEGF in the LC patients was $198 \pm 130 \mathrm{pg} / \mathrm{ml}$. This LC group VEGF value was higher than the mean VEGF value in the control group, but the difference was not statistically significant $\left(\mathrm{p}_{2}=0.06\right)$. At subgroup analyses, VEGF values decreased as CTP stage increased (Child A-207 \pm 89 $\mathrm{pg} / \mathrm{ml}$, Child B-189 $\pm 173 \mathrm{pg} / \mathrm{ml})$, but the difference between the two groups was not statistically significant $(p=1)$. The relevant data are shown in Figure 1. The ROC analysis showed that VEGF above $115 \mathrm{pg} / \mathrm{ml}$ predicted the development of chronic hepatitis with 67\% specificity and $79 \%$ sensitivity (Figure 2), but any VEGF level was unable to predict the development of LC.

\section{Discussion}

Degree of liver fibrosis is a factor of prognostic importance in terms of treatment outcomes in patients with $\mathrm{CHC}^{14}$. Liver biopsy is still the gold standard in determining the grade and stage of liver disease $\mathrm{e}^{14,15}$. Due to the difficulty and complications of this invasive procedure, investigation into methods of diagnosis and follow-up with non-invasive methods is continuing. In that context, there is a growing focus on VEGF, because the VEGF value evaluation is less invasive procedure than biopsy to show liver damage and the disease progression.

Various publications have examined the role of VEGF in conditions such as the diverse liver diseases and 
Table 1. Demographic and biochemical characteristics of the patient and control groups with average values and standard deviations

\begin{tabular}{|c|c|c|c|c|c|}
\hline & Chronic Hepatitis Group (n: 34) & Liver Cirrhosis Group (n: 10) & Control Group (n: 28) & $p_{1}$ & $\mathrm{p}_{2}$ \\
\hline Age (years) & $51 \pm 13$ & $69 \pm 8$ & $52 \pm 18$ & 0.538 & 0.003 \\
\hline AST (U/L) & $54 \pm 66$ & $68 \pm 50$ & $24 \pm 13$ & 0.001 & 0.001 \\
\hline ALT (U/L) & $63 \pm 61$ & $42 \pm 33$ & $21 \pm 14$ & 0.001 & 0.2 \\
\hline Alb (g/dl) & $4.0 \pm 0.3$ & $2.7 \pm 0.5$ & $4.2 \pm 0.2$ & 0.1 & 0.001 \\
\hline PT (sec) & $14 \pm 0.9$ & $18 \pm 3.6$ & $13 \pm 1.5$ & 0.1 & 0.001 \\
\hline VEGF (pg/ml) & $255 \pm 237$ & $198 \pm 130$ & $78 \pm 27$ & $<0.001$ & 0.06 \\
\hline Serum HCV RNA (copy/ml) $10^{3}$ & $4.503 \pm 11.285$ & $14.010 \pm 30.479$ & - & $<0.001$ & $<0.001$ \\
\hline
\end{tabular}

$\mathrm{p}_{1}$, comparison of the CHC and control groups; $\mathrm{p}_{2}$, comparison of the LC and control groups; $n$, patient number.

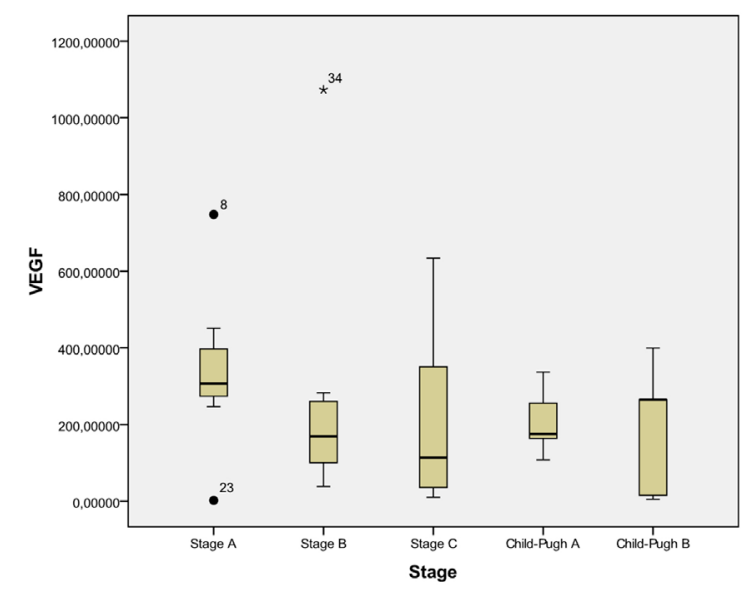

Figure 1. The mean VEGF values of the subgroup.

hepatocellular cancer ${ }^{16-21}$. Some studies have reported low VEGF levels in patients with chronic hepatocellular failure ${ }^{16,17}$, while others have reported VEGF level elevation ${ }^{18,19}$. High VEGF levels have also been reported in patients with LC and experimentally induced cirrhosis $^{20,21}$. We also determined high VEGF levels in both the CHC and LC groups, however this elevation was only significant in the CHC group.

According to Akiyoshi et al. ${ }^{16}, 133$ patients involved [21 with acute hepatitis (AH), 40 with $\mathrm{CH}, 34$ with LC, 16 with fulminant hepatitis, 10 with primary biliary cirrhosis, and 12 with autoimmune hepatitis], reported high VEGF levels in the AH group and low levels in the $\mathrm{CH}$ and $\mathrm{LC}$ groups. We were unable to perform such an evaluation due to the absence of an AH group in our study. In contrast to Akiyoshi et al. ${ }^{16}$, we found VEGF levels were higher in $\mathrm{CH}$ and LC groups. These discrepancies may be because the patients in the $\mathrm{CH}$ group in their study, included subjects associated with hepatitis B as well as hepatitis C. Variations in terms of male-female ratio and age in the two studies may have also affected the results. Further

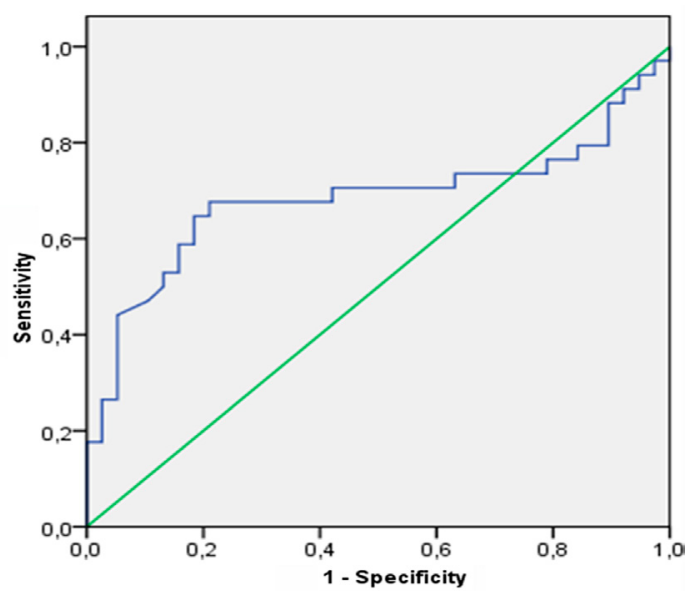

Figure 2. The ROC curve for VEGF $115 \mathrm{pg} / \mathrm{ml}$.

studies with larger patient groups may shed more light on the relationship between underlying primary disease and VEGF. Akiyoshi et al. ${ }^{16}$ also reported no correlation between serum VEGF levels and fibrosis scores in the CHC group, while VEGF levels decreased as fibrosis grade increased in the $\mathrm{CHC}$ group in our study. According to Desideri et al. ${ }^{17}$, which included 151 patients ( 77 with $\mathrm{CH}$ and 74 with LC), found low serum VEGF levels in both the $\mathrm{CH}$ and LC groups compared to the control group and that VEGF levels decreased as fibrosis in the patients with CHC increased.

In addition, Amarakurpar et al. ${ }^{18}$ showed that there is angiogenesis in $45.5 \%$ of CHC patients by VEGF positivity while CD34 was negatively at liver tissue cytology in the cases. CD34 and VEGF were determined in $20.9 \%, 46.5 \%, 75 \%$, and $80 \%$ of fibrosis stage $1,2,3$, and 4 cases, respectively, and angiogenesis was reported to increase in line with fibrosis levels. As evaluated by Selcado et $\mathrm{al}^{19}$., 36 patients with $\mathrm{CHC}$ were treated with a combination of pegylated interferon alpha- $2 \mathrm{~b}$ and ribavirin. They reported increased VEGF and angiopoietin-2 (Ang-2) levels before treatment, while 
a significant decrease was determined in both factors after treatment. The authors concluded that serum VEGF and Ang-2 were practical, non-invasive, and useful markers of disease progression and a treatment for patients with CHC. The role of VEGF in experimentally-induced fibrogenesis in rats was investigated by Rosmorduc et $\mathrm{al}^{20}$. They examined the potential roles of VEGF and fibroblast growth factor-2 (FGF-2) in experimental fibrogenesis established via bile duct ligation. They reported VEGF and FGF-2 in less than 3\% of normal rat hepatocytes, while two weeks after ligation, VEGF expression was determined in more than $95 \%$ of hepatocytes ${ }^{20}$. In another study of cirrhosis experimentally-induced with diethylnitrosamine (DEN) in rats, it was reported that the progression of liver fibrosis was related to hepatocellular hypoxia and angiogenesis, and the microvessel density was correlated with the release of VEGF and its receptor Flt-1 in the liver ${ }^{21}$.

In conclusion, in the present study, it was assumed that the higher VEGF values in the CHC and CLC groups compared to the control group occurred in association with intrahepatic hypoxia resulted from the continuing necroinflammatory process and the accompanying fibrotic process in the liver. Mean VEGF values in the LC group were higher than those of the control group, but not statistically significantly higher, may be due to the low number of patients in the LC group. VEGF levels in liver diseases increased during acute hepatitis and chronic hepatitis healing phases. Therefore, we conclude this is due to increasing regeneration process and in association with the HSC hyperfunction.

According to our study results, VEGF levels decreased during the passage from $\mathrm{CH}$ to cirrhosis and increased compared to healthy individuals-Therefore, VEGF follows a parallel course to the inflammatory and regenerative process accompanying the liver disease, and it may be a marker that can indicate the progression of the hepatic disease. Limitation of this study is the relatively small sample size. There is a need for more casecontrolled trials to take more information on this topic.

\section{References}

1. http://www.who.int/news-room/fact-sheets/detail/hepatitis-c (Accessed 10.02.2019)

2. Aguilera V, Berenguer M. Hepatitis $C$ and fibrosis. Rev EspEnfern Dig 2004;96(6):402-14.

3. Medina J, Arroyo AG, Sanchez-Madrid F, Moreno-Otero R. Angiogenesis in chronic inflammatory liver disease. Hepatology 2004;39;1185-95.
4. Chaparro M, Sanz-Cameno P, Trapero-Marugán M, GarcíaBuey L, Moreno-Otero R. Mechanisms of angiogenesis in chronic inflammatory liver disease. Annals of Hepatology 2007;6(4):208-13.

5. Soria JC, Fayette J, Armand JP. Molecular targeting: targeting angiogenesis in solid tumors. Annals of Oncology 2004;15(4): iv223-iv7.

6. Veikkola T, Alitalo K. VEGF's, receptors and angiogenesis. Seminars in Cancer Biology 1999;9:211-20.

7. Vincenti V, Cassano C, Rocchi M, Persico G. Assignment of the vascular endothelial growth factor gene to human chromosome 6p21 3. Circulation 1996;15(93):1493-5.

8. Huang YH, Chen MH, Guo QL, Chen YX, Zhang LJ, Chen $\mathrm{ZX}$ et al. Interleukin-10 promotes primary rat hepatic stellate cell senescence by upregulating the expression levels of p53 and p21. Mol Med Rep 2018;17(4):5700-7.

9. Aydın MM, Akçalı KC. Liver fibrosis. Turk J Gastroenterol 2018:29:14-21.

10. Ankoma-Sey V, Wang Y, Da1 Z. Hypoxic Stimulation of Vascular Endothelial Growth Factor expression in activated rat hepatic Stellate cells. Hepatology 2000;31(1):141-8.

11. Ishak K, Baptista A, Bianchi L, Callea F, Groote JD, Gudat F. Histolgical grading and staging of chronic hepatitis. Journal of Hepatology 1995;22:696-9.

12. Child CG, Turcotte JG. Surgery and portal hypertension. Philadelphia. Major Probl Clin Surg 1:1-85.

13. Pugh RN, Murray-Lyon IM, Dawson JI, Pietroni Mc, Williams R. Transection of the oesophagus for bleeding oesophageal varics. Br J Surg 1973;60(8):646-9.

14. Pohl A, Behling C, Oliver D, Kilani M, Monson P, Hassanein T. Serum aminotransferase levels and platelet counts as predictors of degree of fibrosis in chronic hepatitis $\mathrm{C}$ virus infection. Am J Gastroenterol 2001;3142-6.

15. Sheth SG, Flamm SL, Gordon FD, Chopra S. AST/ ALT ratio predicts cirrhosis in patient with chronic hepatitis $\mathrm{C}$ virus infection. Am J Gastroenterol 1998;93:44-8.

16. Akıyoshi F, Sata M, Suzuki H, Uchimura Y, Mitsuyama K, Matsuo K et al. Serum vascular endothelial growth factor levels in varius liver diseases. Dig Dis Sci 1998;1:41-5.

17. Desideri G, Ferri C. Circulating vascular endothelial growth factor levels are decreased in patients with chronic hepatitis and liver cirrhosis depending on the degree of hepatic damage. Clin Sci 2000;99:159-60.

18. Amarapurkar AD, Amarakurpar DN, Vibhav S, Patel ND. Angiogenesis in chronic liver disease. Ann Hepatol 2007;6:170-3.

19. Salcedo XM, Medina J, Sanz-CamenoP, García-Buey L, MartínVilchez S, Borque MJ, et al. The potential of angiogenesis soluble markers in chronic hepatitis C. Hepatology 2005;42:696-701.

20. Rosmorduc O, Wendum D, Corpechot C, Galy B, Sebbagh $\mathrm{N}$, Raleigh J, et al. Hepatocellular hypoxia-induced vascular endothelial growth factor expression and angiogenesis in experimental biliary cirrhosis. Am J Pathol 1999; 155(4):1065-73.

21. Corpechot C, Barbu V, Wendum D, Kinnman N, Rey C, Poupon R, et al. Hypoxia-induced VEGF and collagen I expression are associated with angiogenesis and fibrogenesis in experimental cirrhosis. Hepatology 2002;35:1010-21. 